Asian Journal of Managerial Science

ISSN: 2249-6300 Vol.7 No.2, 2018, pp. 47-53

(C) The Research Publication, www.trp.org.in

\title{
An Assessment of Profitability and Efficiency of Commercial Banks in India
}

\author{
Shradha H. Budhedeo \\ Associate Professor, Department of Business Economics, Faculty of Commerce \\ M. S. University of Baroda, Vadodara, Gujarat, India \\ E-Mail: shradhamsu@gmail.com
}

\begin{abstract}
Efficiency and stability of the banking sector is a pre-requisite to economic growth of the nation. The banking industry has undergone phenomenal transformation over the past six decades since independence. Banks have shifted from traditional methods of banking to newer modern systems. This has led to impressive growth of commercial banks in India. In the year 2007, financial crisis loomed over the global economy with severe adverse effects on many western economies. In comparison, India stood poised as the fastest growing emerging market economy in the face of turmoil and pessimism. Although India stood strong, many banks started witnessing a change in their growth path during the post global financial crisis period. The public sector banks witnessed major setbacks with decline in their financial performance. In this light, the objective of the study is defined; so as to determine the role of efficiency and profitability indicators on the performance of bank groups. The findings of the study reveal that foreign banks have shown outstanding profitability performance and excellent management efficiency. It is the private sector banks that have outperformed the competing bank groups in terms of earning efficiency. Public sector banks have lagged behind with deteriorating profitability and efficiencies during the analysis period.

Keywords: Profitability, Management, Earning, Efficiency, Commercial Banks, Ratio Analysis, Performance, Public Sector Banks, Private Sector Banks, Foreign Banks, Bank Groups, India
\end{abstract}

\section{INTRODUCTION}

Efficiency and stability of the banking sector is a p rerequisite to economic growth of the nation. The banking industry has undergone phenomenal transformation over the past six decades or more. This has led to impressive growth of commercial banks in India. Number of commercial bank branches has increased from 4067 in 1956 to $1,15,143$ in 2015. The average population per bank office has gone down from an oppressive 98,000 in 1956 to a manageable 10,300 in 2015. Deposits as a ratio of national income have increased from a low of $10 \%$ in 1956 to as high as $80 \%$ in 2015.The entire banking sector has evolved enormously after independence. Post the nationalisation drive initiated by the government of India, public sector banks dominated the banking industry for almost two decades contributing three-fourth of banking business in India. After 1985, there were serious issues with the public sector banks. Lack of proper risk management systems, missing regulatory and prudential norms, and increasing non-performing assets led to weakening of public sector banks. In this light, the Narasimham Committee was constituted to look into the problems of the banking sector and suggest corrective measures. In succession to the structural reforms introduced in the country, Narasimham Committee ushered in the financial sector reforms in 1993.

The post-reform period was a major upset for Public Sector Banks with increasing and furious competition due to influx of new private sector banks and foreign banks into the banking sphere. Public Sector Banks could not sustain competition for long from the new competitive banks and their financial performance started waning. The reform measures started taking shape by the end of the decade. Prudential norms were put in place, consolidation, deregulation and recapitalization gave a new hope to realign public sector banks in specific and the banking industry in general. Public sector banks moved on the path of gradual recovery and started showing improvement in their performance.

The year 2007 marked severe crisis in the global economy. The financial crisis that loomed over the globe had severe adverse effects on many economies. A major part of the world was dragged into a severe economic slowdown and recession. In comparison to the advanced economies that were on the verge of collapse, India emerged as a far more resilient, dynamic and globalizing market economy. India stood poised as the fastest growing emerging market economy in the face of turmoil and pessimism. Although India stood strong, many banks started witnessing a change in their growth path. The public sector banks witnessed major setbacks. The performance of public sector banks declined to the extent that they lagged behind their private counterparts, and exhibited a sharp fall in their return on equity, return on assets and net interest margins. The gross non-performing assets of public sector banks shot up from $2.6 \%$ in 2006 to a lofty $11 \%$ in 2016 , against $4 \%$ of the private sector and foreign banks.

In the recent years, the entire banking sector has been plagued by issues of rising bad loans and bank failures. Non-performing assets is increasing in the banking industry and has become a serious threat to the banks' existence and survival. Rising debts, non-repayment issues, and loan defaulters have become an area of major concern; which is now the prime focus of the policy makers and the government. 
The government has been adopting various reform measures towards targeting the issue of NPAs, recapitalization and revival of sick banks. Some of the initiatives are Indradhanush plan, Asset Quality Review (AQR) for transparency in recognition and classification of NPAs, Sarfaesi Act, Asset Reconstruction Companies, Bail-in and Bail-out packages, Insolvency and Bankruptcy Code (IBC), restructuring of large NPA accounts, transparency and professionalism in the appointment process for top positions in public sector banks. The Indian Banking Industry has traversed a long way. There have been major transitions and transformations in the banking history. Banks have shifted from traditional methods of banking to new domains as technology based banking and digital banking. Large numbers of studies have been undertaken on the subject of bank performance in India. Still, continuous measurement and evaluation of bank performance is imperative. Against this background, the study attempts to review, measure and analyze the performance of Scheduled Commercial Bank Groups in India on the basis of two broad parametersProfitability and Efficiency outcome of banks. For this purpose, the scheduled commercial banks considered for the study are public sector banks, private sector banks and foreign banks (bank groups). The study aims at determining the role of varied efficiency and profitability indicators on the performance of each bank group.

The present study is spread over five sections. Section one introduces the study and states its objective. Section two traces a brief review of literature on the subject. Section three presents the methodology used in the study, variables selected for examining the profitability and efficiency of bank groups, time period of the study and sources of data. Section four reports the estimated results and covers the performance analysis. Section five concludes the study.

\section{REVIEW OF LITERATURE}

Batra (1996) investigated the impact of policy constraints on the profitability of Indian scheduled commercial banks in pre and post nationalization period. A number of financial ratios and double log-linear equations were estimated for the period $1955 \mathrm{t}$ o 1987. It was found that loans and advances in the bank asset portfolio are an important policy variable along with SLR, CRR and branch expansion in explaining bank profitability.

Li et al. (2001) examined the financial performance of Chinese banks by using financial ratio analysis. The time period for the study relates to the major transitions in the Chinese banking sector during 1996-1999. The results reveal low profitability of state-owned commercial banks. The Chinese banks generated lower returns with higher financial risks than their western counterparts.

Mohan and Ray (2004) have attempted a comparative performance analysis of public, private and foreign bank groups in India. Data envelopment analysis and revenue maximization efficiency methods were used to study the performance of banks for the period 1992-2000. The study found public sector banks and foreign banks to have performed significantly better than private sector banks.

Sree Rama Murthy (2004) tried to estimate financial ratios of major commercial banks in Oman for the period 1997 to 2003. The ratios used in the study were divided into six broad categories - liquidity management ratios, interest rate risk management ratios, credit risk management ratios, capital account management ratios, cost management ratios and profitability management ratios. The study analyzed six banks on the basis of these ratios and the results reveal significant difference in the ratios of selected banks.

Nimalathasan (2008) conducted a comparative study of financial performance of banking sector in Bangladesh. The study used CAMELS rating system for assessing 48 Banks in Bangladesh for the period 1999-2006. The outcomes of the study show that only 3 banks were rated strong while 31 banks were rated satisfactory and 7 banks turned out to be fair. 5 ba nks were found to exhibit marginal performance and the remaining 2 banks got unsatisfactorily rating.

Kumbirai and Webb (2010) investigated he financial performance of commercial banks in South Africa for the time period 2005-2009. Financial ratios were estimated to examine profitability, liquidity and credit quality of five large commercial banks. In the initial years, bank performance improved but the trend changed significantly for the worse after the global financial crisis in 2007.

Boolaky and Auhammud (2011) aimed at assessing Mauritius banks by determining the factors that contribute to their performance. The study used financial ratios to understand the performance of financial intermediaries. Regression analysis was used for data analysis, for 10 Mauritian banks over the period 2006-2009. The major determinants of financial performance of Mauritius banks were identified as return on assets, levels of credit risk, liquidity, interest margin, market concentration and inflation.

Koundal (2012) measured the relative performance of Indian commercial bank groups for the period 2007-08 to 2010-11. Bank groups considered for the study are - public sector banks, old private sector banks, new private sector banks and foreign banks. Ratio analysis was engaged to compare the performance of bank groups. The study concluded that public sector banks improved their individual profitability position but failed to beat the performance of foreign banks and private sector banks.

Singh and Tandon (2012) examined the financial performance of State Bank of India and ICICI Bank for the period 2007-08 to 2011-12. To compare the financial performance of the selected banks, ratio analysis was used. The study found that the State Bank of India group had performed better than ICICI Bank. On the whole, State Bank of India group was financially sound but when it comes to deposits and expenditure, ICICI Bank had performed better. 
Goel and Rekhi (2013) assessed the relative performance of Indian banks for the period 2009 to 2012. For this purpose, three public sector banks and three private sector banks were chosen. Using ratio analysis, the study found that new banks were more efficient as compared to old banks. However, public sector banks were not as profitable as private sector banks.

Haque (2014) categorized Indian banks into different bank groups - public sector banks, nationalized banks, SBI and group, old private sector banks, new private sector banks and foreign banks. The study tried to analyze the financial performance of these bank groups for the period 2009 to 2013. Ratio analysis and ANOVA techniques were employed to study the difference in profitability between bank groups. The results showed that there was no significant difference between bank groups with respect to return on assets and net interest margin. However, significant difference did exist in terms of return on equity.

Islam (2014) attempted to measure financial performance of National Bank Limited; the largest private commercial bank in Bangladesh, for the period 2008-2013. Financial ratio analysis was employed to overview the financial performance in terms of profitability, liquidity and credit performance. The findings of the study serve as a cue for formulating appropriate policies for improving bank performance.

Malyadri and Sirisha (2015) discussed the trends in parameters affecting the financial stability of Indian bank groups. The period under study was from 2006 to 2013. CAGR was used to analyze the parameters of bank groups. The results of the study strongly supported that private sector bank group surpassed other bank groups in terms of all the parameters; succeeded by public sector banks and then foreign banks.

Mittal (2017) tried to compare the performance of public sector banks with that of private sector banks in India for the period 2005 to 2016 . The major objective of the study was to measure the health of the banking industry with respect to the size of non-performing assets. To analyze the growth of non-performing assets, different ratios were used. The study found that the extent of non-performing assets was comparatively more in public sector banks.

Adwani (2018) tried to compare the productivity of employees of top public and private sector banks for the year 2016-17. The study evaluated different ratios for these banks to analyze the efficiency of employees. It was observed that for Indian banks, public sector banks had higher business per employee but poor profit per employee as compared to private sector banks.

Sharma and Sharma (2018) analyzed the financial performance of three selected Indian commercial banks, namely, Punjab National Bank, Canara Bank and State Bank of India; for the period 2016-17. Using financial ratio analysis, the study concluded that State Bank of India dominates the banking scenario, and has outperformed Punjab National Bank and Canara Bank for majority of the indicators.

\section{METHODOLOGY}

The aim of the study is to measure, analyze and compare the performance of bank groups in India on the basis of two important parameters - profitability and efficiency. This analysis is carried out for three bank groups, namely public sector banks (PSBs), private sector banks (PvtSBs), and foreign banks (FBs). Various ratios or indicators have been used in the study to assess and analyze the profitability and efficiency performance of bank groups. Profitability ratio for bank groups has been derived from spread and burden ratios. In order to examine the efficiency level of bank groups, the study measures efficiency on two grounds Management Efficiency, and Earning Efficiency.

The ratios established for measuring profitability of bank groups are:

1. Interest Earned Ratio: Total Interest Earned as a ratio of Total Business

2. Interest Paid Ratio: Total Interest Paid as a $r$ atio of Total Business

3. Spread Ratio (SR): The difference of Interest Earned Ratio and Interest Paid ratio

(Spread Ratio = Interest Earned Ratio - Interest Paid Ratio)

4. Manpower Expenses Ratio: Total Wage Bill as a ratio of Total Business

5. Establishment Expenses Ratio: Other Establishment Expenses as a ratio of Total Business

6. Non-interest Income Ratio: Non-interest income as a ratio of Total Business

7. Burden Ratio (BR): Manpower Expenses Ratio + Establishment Expenses Ratio - Non-interest Income Ratio

8. Profitability Ratio (PR): Difference of Spread Ratio and Burden Ratio $(\mathrm{PR}=\mathrm{SR}-\mathrm{BR})$

For assessing management efficiency of bank groups, the following ratios have been constructed:

1. Business per Employee: Total Business (Deposits + Advances) as a ratio of Total Employees

2. Profit per Employee: Profit as a ratio of Total Employees

The earning efficiency of bank groups has been examined on the basis of following ratios:

1. Credit-Deposit Ratio: Credit (Advances) as a ratio of Total Deposits

2. Operating Efficiency: Operating Expenses as a ratio of Net Interest Income

where, Net Interest Income $=$ Interest Earned - Interest Paid

3. Percentage Growth in Profit/Loss 
The above indicators or ratios have been developed using the Ratio Analysis. To trace the strengths and weaknesses of scheduled commercial banks in India, financial ratios are developed by establishing appropriate ratios between items of balance sheet and profit and loss account. This method is useful in understanding the growth and performance of banks by looking at the trends in the ratios. The time period of the study for the performance analysis is 2010-11 to 2016-17. The entire empirical analysis is based on secondary data obtained from different sources of Reserve Bank of India publications such as Basic Statistical Returns of Scheduled Commercial Banks in India, Statistical Tables Relating to Banks in India, Handbook of Statistics on Indian Economy, and RBI Bulletin.

\section{ESTIMATED RESULTS AND ANALYSIS}

The study computed a number of financial ratios as stated in the methodology and arrived at the results on profitability and efficiency performance of commercial bank groups. The estimated results are presented and analysed in this section.

\section{A. Performance of Scheduled Commercial Banks: Profitability of Bank Groups}

The ratios selected and computed for measuring the profitability performance of the bank groups are displayed in Tables I, II and III. Table I presents the derivation of interest spread ratio from interest earned and interest paid by bank groups. Table II shows the calculation of the burden ratio for bank groups. The last Table III establishes the profitability ratios attained by bank groups as derived from the previous two, that is, spread ratio and burden ratio.

Table I reveals the spread ratio of bank groups - Public Sector Banks (PSBs), Private Sector Banks (PvtSBs), and Foreign Banks (FBs), over the study period. The interest earned ratio for $\mathrm{FBs}$ has averaged at $6.9 \%$, at $6.1 \%$ for PvtSBs and at 5.2\% for PSBs. The interest paid ratio for PSBs and PvtSBs is in the same range $3.6 \%-3.8 \%$. However, the FBs have a relatively low interest paid ratio of $3 \%$. As such, the spread ratio which is the difference of the interest earned and interest paid ratios is the highest $(3.9 \%)$ for the FBs, followed by that of PvtSBs (2.3\%) and then PSBs (1.6\%).

TABLE I SPREAD RATIO OF BANK GROUPS (in \%)

\begin{tabular}{|l|c|c|c|c|c|c|c|c|c|}
\hline \multirow{2}{*}{ Year } & \multicolumn{2}{|c|}{ Interest Earned Ratio } & \multicolumn{2}{|c|}{ Interest Paid Ratio } & \multicolumn{3}{|c|}{ Spread Ratio } \\
\cline { 2 - 11 } & PSBs & PvtSBs & FBs & PSBs & PvtSBs & FBs & PSBs & PvtSBs & FBs \\
\hline $2010-11$ & 4.8 & 5.4 & 6.5 & 3.0 & 3.2 & 2.4 & 1.8 & 2.2 & 4.1 \\
\hline $2011-12$ & 5.5 & 6.3 & 7.1 & 3.7 & 4.1 & 3.0 & 1.8 & 2.2 & 4.2 \\
\hline $2012-13$ & 5.4 & 6.6 & 7.7 & 3.8 & 4.2 & 3.4 & 1.6 & 2.3 & 4.3 \\
\hline $2013-14$ & 5.3 & 6.4 & 7.1 & 3.7 & 4.1 & 3.3 & 1.6 & 2.4 & 3.8 \\
\hline $2014-15$ & 5.3 & 6.3 & 6.9 & 3.8 & 3.9 & 3.3 & 1.5 & 2.4 & 3.6 \\
\hline $2015-16$ & 5.3 & 6.1 & 6.4 & 3.8 & 3.7 & 2.9 & 1.5 & 2.4 & 3.4 \\
\hline $2016-17$ & 5.0 & 5.8 & 6.4 & 3.5 & 3.5 & 3.0 & 1.5 & 2.4 & 3.5 \\
\hline Mean & 5.2 & 6.1 & 6.9 & 3.6 & 3.8 & 3.0 & 1.6 & 2.3 & 3.9 \\
\hline S.D. & 0.3 & 0.4 & 0.5 & 0.3 & 0.4 & 0.3 & 0.1 & 0.1 & 0.3 \\
\hline CAGR (\%) & 0.8 & 1.4 & -0.2 & 2.6 & 1.4 & 3.4 & -2.9 & 1.4 & -2.8 \\
\hline
\end{tabular}

TABLE II BURDEN RATIO OF BANK GROUPS (IN \%)

\begin{tabular}{|c|c|c|c|c|c|c|c|c|c|c|c|c|}
\hline \multirow{2}{*}{ Year } & \multicolumn{3}{|c|}{ Manpower Expenses Ratio } & \multicolumn{3}{|c|}{ Establishment Expenses Ratio } & \multicolumn{3}{|c|}{ Non-interest Income Ratio } & \multicolumn{3}{|c|}{ Burden Ratio } \\
\hline & PSBs & PvtSBs & FBs & PSBs & PvtSBs & FBs & PSBs & PvtSBs & FBs & PSBs & PvtSBs & FBs \\
\hline $2010-11$ & 0.7 & 0.7 & 1.2 & 1.1 & 1.5 & 2.9 & 0.6 & 1.2 & 2.5 & 1.2 & 1.1 & 1.6 \\
\hline 2011-12 & 0.7 & 0.7 & 1.1 & 1.0 & 1.6 & 2.6 & 0.6 & 1.2 & 2.2 & 1.1 & 1.1 & 1.6 \\
\hline $2012-13$ & 0.6 & 0.7 & 1.1 & 1.0 & 1.6 & 2.6 & 0.6 & 1.2 & 2.0 & 1.1 & 1.1 & 1.7 \\
\hline 2013-14 & 0.6 & 0.7 & 1.0 & 1.0 & 1.6 & 2.4 & 0.6 & 1.2 & 2.1 & 1.1 & 1.0 & 1.3 \\
\hline 2014-15 & 0.6 & 0.7 & 1.0 & 1.0 & 1.6 & 2.2 & 0.6 & 1.2 & 2.0 & 1.1 & 1.0 & 1.1 \\
\hline $2015-16$ & 0.7 & 0.6 & 0.8 & 1.1 & 1.6 & 2.0 & 0.6 & 1.2 & 1.5 & 1.2 & 1.0 & 1.3 \\
\hline 2016-17 & 0.7 & 0.6 & 0.9 & 1.1 & 1.6 & 2.1 & 0.8 & 1.3 & 2.0 & 1.0 & 0.9 & 1.0 \\
\hline Mean & 0.7 & 0.7 & 1.0 & 1.1 & 1.6 & 2.4 & 0.6 & 1.2 & 2.1 & 1.2 & 1.1 & 1.3 \\
\hline S.D. & 0.0 & 0.0 & 0.2 & 0.1 & 0.0 & 0.3 & 0.1 & 0.1 & 0.3 & 0.1 & 0.1 & 0.3 \\
\hline CAGR (\%) & -1.3 & -1.5 & -6.0 & 0.9 & 0.6 & -5.0 & 4.9 & 2.3 & -3.9 & -3.1 & -3.0 & -7.6 \\
\hline
\end{tabular}


Table II shows the burden ratio of bank groups as computed from the difference of total manpower and establishment expenses ratios and non-interest income ratio. Manpower expenses ratio is very high for PSBs and PvtSBs $(0.7 \%)$ but only $0.1 \%$ for FBs. On the other hand, the establishment expenses are very high for FBs $(2.4 \%)$ and lowest for PSBs at $1.1 \%$. Similar trend is observed for non-interest income of bank groups. FBs have attained the highest (2.1\%) while PSBs the lowest $(0.6 \%)$ non-interest income ratios.
Although the establishment expenses is much higher for FBs in comparison to other bank groups, their ability to manage with very low manpower expenses and capacity of generating higher non-interest income has enabled the FBs to escape extreme deterioration in their burden ratios. In contrast, domestic banks have high manpower expenses but lower establishment expenses and non-interest incomes. The burden ratio for all the three bank groups is in the range of $1.1 \%-1.3 \%$.

TABLE III PROFITABILITY RATIO OF BANK GROUPS

\begin{tabular}{|l|c|c|c|c|c|c|c|c|c|}
\hline \multirow{2}{*}{ Year } & \multicolumn{3}{|c|}{ Spread Ratio (SR) } & \multicolumn{3}{c|}{ Burden Ratio (BR) } & \multicolumn{3}{c|}{ Profitability Ratio (PR) } \\
\cline { 2 - 11 } & PSBs & PvtSBs & FBs & PSBs & PvtSBs & FBs & PSBs & PvtSBs & FBs \\
\hline $2010-11$ & 1.8 & 2.2 & 4.1 & 1.2 & 1.1 & 1.6 & 0.6 & 1.1 & 2.5 \\
\hline $2011-12$ & 1.8 & 2.2 & 4.2 & 1.1 & 1.1 & 1.6 & 0.7 & 1.1 & 2.5 \\
\hline $2012-13$ & 1.6 & 2.3 & 4.3 & 1.1 & 1.1 & 1.7 & 0.6 & 1.2 & 2.6 \\
\hline $2013-14$ & 1.6 & 2.4 & 3.8 & 1.1 & 1.0 & 1.3 & 0.5 & 1.4 & 2.6 \\
\hline $2014-15$ & 1.5 & 2.4 & 3.6 & 1.1 & 1.0 & 1.1 & 0.5 & 1.4 & 2.5 \\
\hline $2015-16$ & 1.5 & 2.4 & 3.4 & 1.2 & 1.0 & 1.3 & 0.4 & 1.4 & 2.2 \\
\hline $2016-17$ & 1.5 & 2.4 & 3.5 & 1.0 & 0.9 & 1.0 & 0.5 & 1.5 & 2.5 \\
\hline Mean & 1.6 & 2.3 & 3.8 & 1.1 & 1.0 & 1.4 & 0.5 & 1.3 & 2.4 \\
\hline S.D. & 0.1 & 0.1 & 0.3 & 0.1 & 0.1 & 0.3 & 0.1 & 0.2 & 0.2 \\
\hline CAGR (\%) & -2.9 & 1.4 & -2.8 & -3.1 & -3.0 & -7.6 & -2.6 & 4.7 & -0.2 \\
\hline
\end{tabular}

Table III exhibits the trend in profitability ratios of bank groups, as net of spread and burden ratios. Over the analysis period of the study, the FBs have clearly shown outstanding profitability performance with an average profitability ratio of $2.4 \%$.

The PvtSBs achieve a profitability ratio of only $1.3 \%$, while PSBs lag far behind with a low profitability ratio of $0.5 \%$.
B. Performance of Scheduled Commercial Banks: Efficiency of Bank Groups

The ratios identified for measuring the level of efficiency of bank groups reveal management efficiency as well as earning efficiency of bank groups. Management efficiency indicators are presented in Table IV and those of earning efficiency in Table V.

TABLE IV MANAGEMENT EFFICIENCY OF BANK GROUPS

\begin{tabular}{|l|c|c|c|c|c|c|}
\hline \multirow{2}{*}{ Year } & \multicolumn{2}{|c}{ Business Per Employee } & \multicolumn{4}{c|}{ Profit Per Employee } \\
\cline { 2 - 7 } & PSBs & PvtSBs & FBs & PSBs & PvtSBs & FBs \\
\hline $2010-11$ & 101.7 & 95.8 & 157.1 & 0.6 & 0.9 & 2.8 \\
\hline $2011-12$ & 114.7 & 86.2 & 195.6 & 0.5 & 0.9 & 3.6 \\
\hline $2012-13$ & 128.0 & 93.0 & 217.5 & 0.6 & 1.1 & 4.6 \\
\hline $2013-14$ & 140.8 & 99.5 & 259.2 & 0.4 & 1.1 & 4.1 \\
\hline $2014-15$ & 150.0 & 110.3 & 286.6 & 0.4 & 1.2 & 5.0 \\
\hline $2015-16$ & 152.8 & 109.0 & 326.1 & -0.2 & 1.1 & 4.3 \\
\hline $2016-17$ & 158.7 & 118.7 & 321.5 & -0.1 & 1.0 & 5.2 \\
\hline Mean & 135.2 & 101.8 & 251.9 & 0.3 & 1.1 & 4.2 \\
\hline S.D. & 21.2 & 11.3 & 64.5 & 0.3 & 0.1 & 0.8 \\
\hline CAGR (\%) & 7.7 & 3.6 & 12.7 & -7.0 & 1.8 & 11.1 \\
\hline
\end{tabular}

"To calculate CAGR, 2014-15 is taken since the last year as the values for 2015-16 and 2016-17 are negative

Table IV highlights the management efficiency of commercial banks in terms of total business generated per employee and profits realized per employee by the bank groups. FBs attain the highest volume of business per employee as well as profit per employee amounting to an average of $251.9 \mathrm{mn}$ and $4.2 \mathrm{mn}$ respectively. The CAGR 
for FBs is also highest for these two efficiency indicators. Although PSBs manage to generate business worth 135.2 $\mathrm{mn}$ per employee, they get the lowest amount of profits per employee, no more than $0.3 \mathrm{mn}$. CAGR of profit per employee for PSBs has fallen at the rate of $7 \%$. PvtSBs have been able to achieve marginal improvements in their business per employee and profit per employee ratios over time.

TABLE V EARNING EFFICIENCY OF BANK GROUPS

\begin{tabular}{|c|c|c|c|c|c|c|c|c|c|c|c|c|}
\hline \multirow{3}{*}{ Year } & \multicolumn{3}{|c|}{$\begin{array}{c}\text { Credit-Deposit Ratio } \\
(\%)\end{array}$} & \multicolumn{3}{|c|}{$\begin{array}{c}\text { Operating Efficiency } \\
(\%)\end{array}$} & \multicolumn{6}{|c|}{ Percentage Growth of Profit/Loss } \\
\hline & \multirow[b]{2}{*}{ PSBs } & \multirow[b]{2}{*}{ PvtSBs } & \multirow[b]{2}{*}{ FBs } & \multirow[b]{2}{*}{ PSBs } & \multirow[b]{2}{*}{ PvtSBs } & \multirow[b]{2}{*}{ FBs } & \multicolumn{2}{|c|}{ PSBs } & \multicolumn{2}{|c|}{ PvtSBs } & \multicolumn{2}{|c|}{ FBs } \\
\hline & & & & & & & $\begin{array}{c}\text { Profit/ } \\
\text { Loss }\end{array}$ & $\begin{array}{c}\% \\
\text { Growth }\end{array}$ & $\begin{array}{c}\text { Profit/ } \\
\text { Loss }\end{array}$ & $\begin{array}{c}\% \\
\text { Growth }\end{array}$ & $\begin{array}{c}\text { Profit/ } \\
\text { Loss }\end{array}$ & $\begin{array}{c}\% \\
\text { Growth }\end{array}$ \\
\hline 2010-11 & 81.2 & 79.5 & 73.9 & 61.5 & 69.8 & 70.3 & 449001 & - & 177116 & - & 77189 & - \\
\hline 2011-12 & 23.0 & 82.3 & 75.8 & 57.8 & 71.2 & 63.5 & 357138 & -20.5 & 227180 & 28.3 & 94264 & 22.1 \\
\hline $2012-13$ & 91.5 & 81.9 & 75.0 & 61.0 & 68.2 & 60.9 & 505827 & 41.6 & 289954 & 27.6 & 115865 & 22.9 \\
\hline 2013-14 & 82.6 & 84.4 & 74.3 & 65.9 & 66.2 & 62.4 & 370189 & -26.8 & 337541 & 16.4 & 101397 & -12.5 \\
\hline 2014-15 & 80.9 & 86.4 & 73.8 & 67.8 & 66.1 & 61.2 & 375400 & 1.4 & 387347 & 14.8 & 128032 & 26.3 \\
\hline $2015-16$ & 74.7 & 90.3 & 79.2 & 73.3 & 64.9 & 57.5 & -179930 & -147.9 & 413137 & 6.7 & 108275 & -15.4 \\
\hline $2016-17$ & 68.8 & 86.5 & 71.4 & 77.4 & 66.4 & 61.2 & -113887 & 36.7 & 422041 & 2.2 & 129650 & 19.7 \\
\hline Mean & 71.8 & 84.5 & 74.8 & 66.4 & 67.6 & 62.4 & 251962.6 & -19.25 & 322045.1 & 16.0 & 107810.3 & 10.5 \\
\hline S.D. & 22.6 & 3.6 & 2.4 & 7.1 & 2.3 & 4.0 & 278066.1 & 63.5 & 94723.3 & 10.6 & 18767.4 & 19.1 \\
\hline $\begin{array}{l}\text { CAGR } \\
(\%)\end{array}$ & -2.7 & 1.4 & -0.6 & 3.9 & -0.8 & -2.3 & $-4.4^{*}$ & 12.4 & 15.6 & -40.2 & 9.0 & -2.3 \\
\hline
\end{tabular}

*To calculate CAGR, 2014-15 is taken as the last year since the values for 2015-16 and 2016-17 are negative.

Table $\mathrm{V}$ records the status of earning efficiency of bank groups; measured by trends in credit-deposit ratio, operating efficiency ratio, and growth in profit/loss of bank groups. The credit-deposit ratio and operating efficiency ratio are highest for PvtSBs at an average of $84.5 \%$ and $67.6 \%$ respectively. The mean of credit-deposit ratio for PSBs and FBs is in the range of $71 \%-75 \%$ while that of operating efficiency ratio is between $62 \%-67 \%$. Overall, the three bank groups demonstrate healthy earning efficiency positions. Yet, the trends in credit-deposit ratio of PSBs have shown a consistent decline. FBs witnessed fluctuations in their credit-deposit ratio whereas their operating efficiency ratios have been largely falling.

During the analysis period, PSBs show a fall in profits every alternate year. However, in 2015-16, profits dropped drastically by almost $150 \%$ generating huge losses for the government banks. Due to inconsistent performance of PSBs over the study period, the average profits have almost halved as compared to that in 2010-11. PvtSBs have witnessed continuous deterioration in their profit growth. In 2015-16, this bank group confirm a decline in profit growth by half as compared to the previous year. The same trend continued in 2016-17 as well, with growth reducing by twothird of the previous year. The average growth in profits of PvtSBs is $16 \%$.It is interesting to note that during the period of study, FBs also experienced negative profit growth in some years, but they fiercely recovered in the immediate next year. The mean of profit growth is moderate at $10.5 \%$. Among the three bank groups, it is the PvtSBs that have consistently realised profits, despite their slow growth.

\section{CONCLUSION}

1. Spread ratio or the difference of ratios of interest earned and interest paid is the highest for FBs, since their interest paid ratios are relatively less to other bank groups.

2. FBs incur very low manpower expenses as a ratio of their total volume of business, but their establishment costs are very high. At the same time, they also earn high non-interest incomes which prevent their burden ratios from escalating. On the other hand, PSBs accrue huge wage bills and one of the lowest establishment expenses among bank groups. Nevertheless, the burden ratios PSBs are at par with that of FBs on account of very low non-interest income earnings of PSBs.

3. FBs exhibit outstanding profitability performance over the period of study with an average profitability of $2.4 \%$ as a ratio of total volume of business generated. PSBs are miserable with an average profitability ratio of merely $0.5 \%$.

4. The efficiency of bank groups' as judged by parameters of management efficiency reveal high level of managerial efficiency by FBs in terms of the total volume of business per employee and profits per employee realised by FBs.

5. Overall, all the three bank groups' record healthy earning efficiency status in terms of credit-deposit ratio and operating efficiency ratio. Still, the PvtSBs turn out to be the most efficient in this regard. The average growth in profit/loss of bank groups' also clearly highlights the efficiency of PvtSBs, which have consistently realised profits over the analysis period, 
despite slow growth. The ability of FBs to rebound to their previous levels of profit after sustaining huge losses during some periods is a sign of their inherent resilience and elasticity. The mean of profit growth for FBs is moderate at $10.5 \%$.

The overall conclusion from the findings of the study suggests that foreign banks have shown outstanding profitability performance and excellent management efficiency. The private sector banks have outperformed the competing bank groups in terms of earning efficiency. Public sector banks have lagged behind with deteriorating profitability and efficiencies during the analysis period.

\section{REFERENCES}

[1] Batra, A. (1996). Bank Profitability with a Hybrid Profit Function: The Indian Case. Indian Economic Review, 31(2), 223-234.

[2] Li, S., Liu, F., Liu, S., \& Whitmore, G. A. (2001, January). Comparative Performance of Chinese Commercial Banks: Analysis, Findings and Policy Implications, Review of Quantitative Finance and Accounting, 16(2), 149-170.

[3] Mohan, T. T., \& Ray, C. S. (2004). Comparing Performance of Public and Private Sector Banks: A Revenue Maximisation Efficiency Approach, Economic and Political Weekly, 39(12), 20-26.

[4] Sree Rama Murthy, Y. (2004). Financial Ratios of Major Commercial Banks, June. Retrieved from SSRN: https://ssrn.com/abstract=10152 38 or http://dx.doi.org/10.2139/ssrn.1015238.

[5] Nimalathasan, B. (2008). A Comparative Study of Financial Performance of Banking Sector in Bangladesh - An Application of CAMELS Rating, Annals of University of Bucharest, Economic and Administrative Series, 2, 141-152, July. Retrieved from SSRN: https://ssrn.com/abstract=2117189

[6] Kumbirai, M., \& Webb, R. (2010, December). A Financial Ratio Analysis of Commercial Bank Performance in South Africa, African Review of Economics and Finance, 2(1), 30-53.
[7] Boolaky, A., \& Auhammud, K. (2011). An Evaluation of Commercial Banks Performance: The Mauritian Context, Conference Paper, International Conference on Contemporary Mauritius, January. Retrieved from https://www.researchgate.net/publication/281449335

[8] Koundal, V. (2012, September). Performance of Indian Banks in Indian Financial System, International Journal of Social Science \& Interdisciplinary Research, 1(9), 204-213.

[9] Singh, A. B., \& Tandon, P. (2012, November). A Study of Financial Performance: A Comparative Analysis of SBI and ICICI Bank, International Journal of Marketing, Financial Services \& Management Research, 1(11), 56-71.

[10] Goel, C., \& Rekhi, C. (2013). A Comparative Study on the Performance of Selected Public Sector and Private Sector Banks in India, Journal of Business Management and Social Science Research, 2(7), 46-56.

[11] Haque, A. (2014). Comparison of Financial Performance of Commercial Banks: A Case Study in the Context of India (20092013), Journal of Finance and Bank Management, 2(2), 1-14.

[12] Islam, M. A. (2014). An Analysis of the Financial Performance of National Bank Limited using Financial Ratio, Journal of Behavioural Economics, Finance, Entrepreneurship, Accounting and Transport, 2 (5), 121-129.

[13] Malyadri, P., \& Sirisha, S. (2015). An Analytical Study on Trends and Progress of Indian banking Industry, Journal of Business \& Financial Affairs, 4(1). DOI: 10.4172/2167-0234.1000136.

[14] Mittal, R. (2017). The Problem of Rising Non-Performing Assets in Banking Sector in India: Comparative Analysis of Public and Private Sector Banks, International Journal of Management, IT \& Engineering, 7(7), 384-389.

[15] Adwani, V. K. (2018, May). Employees Productivity in Indian Banking: A Comparative Study of Top Public and Private Sector Banks, International Journal of Current Research in Life Sciences, 7(5), 1965-1972.

[16] Sharma, R. P., \& Sharma, A. (2018). A Comparative Appraisal of Financial Performance of Indian Public Sector Banks, International Journal of Economics \& Finance Research \& Applications, 2(1) 3441. 